\title{
ANALISIS MINAT BACA MAHASISWA SEMESTER 5 PGSD UPGRIS
}

\author{
Anggun Dwi Setya Putri ${ }^{1}$, Suyitno \\ Pendidikan Guru Sekolah Dasar, Fakultas Ilmu Pendidikan, Universitas PGRI Semarang \\ e-mail: anjuuundsp@gmail.com
}

\begin{abstract}
Reading becomes one of the most effective activities to get information from various sources, both online and offline. However, today's reading culture let alone reading textbooks seems to have started to decrease. Similarly, young people, especially students. Yet through the process of reading can improve thinking power, sharpen the view, and broaden the horizons. This research uses descriptive quantitative approach. The sample of this research was taken by random sampling technique. Methods of data collection in this study used observation, questionnaires, documentation and interviews. The Data was analyzed by using descriptive analysis percentage. The result of this research shows that the reading interest condition of PGSD UPGRIS students consists of low category $96,96 \%$, medium category $3.04 \%$, while high category and very high $0 \%$. In addition, the obstacles in growing interest in reading students consisting of six indicators namely, physical weakness, intelligence, interests, talents, habits, and the number of student learning expenses produce an average of $42.42 \%$, it was stated as being in the medium category.
\end{abstract}

Keywords: reading interest, students.

\begin{abstract}
Abstrak
Membaca menjadi salah satu kegiatan yang efektif guna mendapatkan informasi dari berbagai sumber, baik secara online maupun offline. Namun, saat ini budaya membaca apalagi membaca buku teks nampaknya sudah mulai berkurang. Begitu pula dengan generasi muda khususnya mahasiswa. Padahal melalui proses membaca dapat meningkatkan daya pikir, mempertajam pandangan, dan memperluas wawasan. Penelitian ini menggunakan pendekatan kuantitatif deskriptif. Sampel penelitian diambil melalui teknik random sampling. Metode pengumpulan data pada penelitian ini menggunakan observasi, angket, dokumentasi dan wawancara. Data dianalisis dengan menggunakan analisis deskriptif persentase. Hasil penelitian menunjukkan kondisi minat baca mahasiswa PGSD UPGRIS terdiri atas kategori rendah sebesar 96,96\%, kategori sedang 3,04\%, sedangkan kategori tinggi dan sangat tinggi $0 \%$. Selain itu, kendala dalam menumbuhkan minat baca mahasiswa yang terdiri dari enam indikator yakni, kelemahan fisik, intelegensi, minat, bakat, kebiasaan, dan banyaknya beban belajar mahasiswa menghasilkan rata-rata sebesar $42,42 \%$ termasuk dalam kategori sedang.

Kata kunci: minat baca, mahasiswa.
\end{abstract}

\section{PENDAHULUAN}

Arus globalisasi pada abad 21 ini menawarkan banyak peluang dan tantangan bagi seluruh masyarakat. Bagi bangsa Indonesia sendiri, globalisasi menuntut adanya sumber daya manusia (SDM) yang profesional dan bermutu tinggi. Hal tersebut bermakna bahwa bangsa Indonesia harus memiliki kepribadian yang berkarakter kuat.

Pada masa mendatang tepatnya tahun 2045 Indonesia akan mengalami bonus demografi yang akan memunculkan generasi emas. Hal ini tentu perlu didukung oleh kualitas pendidikan yang mumpuni dan profesional. Oleh karena itu, pendidikan harus dikelola dengan baik dan benar agar menghasilkan lulusan yang berkualitas guna menghadapi dunia dengan berbagai tantangan dan problematika serta dapat menghasilkan lulusan yang bermutu. Sehingga nantinya bonus demografi Indonesia di 2045 akan menghasilkan generasi emas yang unggul dan mampu menghadapi dunia di abad disrupsi.

$$
\text { Sugiharto (2012) dalam kuliah }
$$

perdana di Universitas Sarjanawiyata 
Tamansiswa menyampaikan delapan langkah untuk menghadapi generasi emas di 2045, yakni: (a) Memberantas Kemiskinan dan Kelaparan Ekstrim, (b) Mencapai Pendidikan Dasar untuk Semua, (c) Mendorong Kesetaraan Gender dan Pemberdayaan, (d) Perempuan Menurunkan Angka Kematian Anak, (e) Meningkatkan Kesehatan Ibu, (f) Memerangi HIV/AIDS, Malaria, dan Penyakit Menular Lainnya, (g) Memastikan Kelestarian Lingkungan Hidup, dan (h) Mengembangkan Kemitraan Global untuk Pembangunan.

Pada bidang pendidikan di perguruan tinggi, tentunya cara untuk menyiapkan generasi emas adalah dengan membangun karakter, kepribadian, kemandirian, dan kekreatifan baik dari segi pendidikan formal maupun nonformal sehingga nantinya akan menjadikan seseorang yang memiliki integritas, berdaya saing, dan menjadi pribadi yang berkualitas dan unggul dalam berbagai bidang.

Seperti halnya dengan kualitas pendidikan di universitas PGRI Semarang. Guna menghasilkan lulusan yang bermutu dan berkualitas sesuai dengan visi dan misi lembaga tentunya memerlukan adanya pengelolaan dan pengejawantahan yang profesional dan terarah dari pendidik sehingga nantinya dapat mentransfer ilmu pengetahuan serta mampu menjadi fasilitator yang baik untuk mahasiswanya. Tidak hanya pendidik, peserta didik dalam hal ini mahasiswa juga berperan sangat penting dalam menghasilkan mutu lulusan yang tidak hanya berpengetahuan namun juga berketerampilan serta mampu bersaing dengan lulusan dari perguruan tinggi lain.

Anggun (2017) menyatakan bahwa "Quality graduates can only be achieved if all of the components required in education has been filled with good and the learning process takes place according to the purpose of education. Therefore the state should be responsible to meet the needs and prepared for all the people in a fair and evenly". Ini berarti kualitas lulusan salah satunya dari perguruan tinggi tidak hanya terletak pada satu komponen, akan tetapi seluruh komponen pendidikan harus ikut berpartisipasi guna mewujudkan tujuan pendidikan.

Salah satu hal yang dapat menunjang kompetensi lulusan yang bermutu dan berkualitas adalah melalui kebiasaan membaca. Menurut Burns, dkk dalam Farida Rahim (2008:1) menyatakan bahwa "kemampuan membaca merupakan sesuatu yang vital dalam suatu masyarakat terpelajar". Oleh karena itu, pembelajaran membaca mempunyai peranan yang sangat penting. Melalui proses membaca dapat meningkatkan daya pikir, mempertajam pandangan, dan memperluas wawasan.

Berdasarkan studi "Most Littered Nation In the World" yang dilakukan oleh Central Connecticut State Univesity pada 2016 lalu, Indonesia dinyatakan menduduki peringkat ke-60 dari 61 negara soal minat membaca. Indonesia persis berada di bawah Thailand (59) dan di atas Bostwana (61). (Pikiran Rakyat, 17 Maret 2017). Sementara itu, kajian yang dilakukan oleh Perpustakaan Nasional pada tahun 2015 menunjukkan bahwa minat baca masyarakat berada pada ketegori rendah atau berada pada angka 25,1. Bahkan bila melihat data dari UNESCO pada tahun 2012 mengungkap minat baca Indonesia hanya 0,001 yang menandakan setiap dari 1000 orang di Indonesia hanya 1 orang yang rajin membaca.

Kurangnya minat baca seseorang tentu berpengaruh terhadap kualitas membaca. Menurut Slameto (2010: 57) minat merupakan kecenderungan yang tetap untuk memperhatikan dan mengenang beberapa kegiatan. Sedangkan Syach (2003: 136) mengemukakan bahwa minat merupakan kecenderungan dan kegairahan yang tinggi atau keinginan yang besar terhadap sesuatu. Seseorang yang memiliki minat baca yang kuat akan diwujudkan dengan melakukan aktivitas membaca bacaan sesuai dengan kesadaran dirinya sendiri. Minat baca muncul melalui proses yang panjang dan memerlukan tahapan 
perubahan yang muncul secara teratur dan berkesinambungan sehingga akan menjadikan seseorang memiliki pengetahuan yang tinggi terhadap suatu hal yang dibaca.

Sama halnya dengan mahasiswa semester 5 PGSD UPGRIS. Guna mewujudkan literasi baca tentu memerlukan adanya minat baca dari masing-masing individu. Akan tetapi, mahasiswa masih memiliki minat baca yang rendah. Sebagaimana hasil survey dan observasi awal terhadap mahasiswa begitu mempri-hatinkan. Bagaimana tidak, saat diberikan pertanyaan bekal apa saja yang mereka bawa saat mengikuti perkuliahan semua tidak bisa menjawab dan cenderung diam. Hampir seluruh mahasiswa menunjukkan bahwa mereka datang hanya dengan niat tanpa menyiapkan atau membaca materi yang sudah atau bahkan yang akan mereka terima ketika perkuliahan. Hal ini tentu sangat menganggu kegiatan pembelajaran dan perkuliahan yang seharusnya dapat berlangsung dengan aktif menjadi pasif.

Alasan-alasan di atas tentu menjadi hal yang harus diperhatikan lebih baik oleh dosen, mahasiswa, maupun lembaga. Dosen sebagai penyalur ilmu dan inspirasi bagi mahasiswa juga harus menjadi contoh untuk meningkatkan minat membaca mahasiswa. Beberapa upaya tentu dilakukan oleh dosen guna menyadarkan mahasiswa bahwa membaca merupakan hal yang sangat penting. Kurangnya minat baca mahasiswa tentu dipengaruhi oleh berbagai faktor, baik faktor internal maupun faktor eksternal.

Berdasarkan paparan di atas mengenai minat dan aktivitas membaca, peneliti tertarik untuk melakukan observasi lebih mendalam lagi terhadap kondisi dan kendala yang dihadapi mahasiswa semester 5 PGSD UPGRIS dalam menumbuhkan minat baca.

\section{METODE PENELITIAN}

Jenis penelitian yang digunakan adalah pendekatan kuantitatif deskriptif yang bertujuan untuk mengungkap masalahmasalah dengan mengumpulkan, menyusun, mengklasifikasikan, menganalisa serta menginterpretasikan data berupa angka atau skor.

Penelitian ini telah dilaksanakan di Program Studi PGSD Universitas PGRI Semarang. Adapun populasi dalam penelitian ini adalah semua mahasiswa semester 5 PGSD UPGRIS tahun pelajaran 2017/2018 sebanyak 495 mahasiswa. Cara pengambilan sampel dalam penelitian ini menggunakan teknik random sampling dengan menentukan sampel berdasarkan hasil undian terhadap nomor urut presensi mahasiswa di kelas yang akan diambil sampelnya..

Data yang dikumpulkan dalam penelitian ini menggunakan observasi, wawancara, dokumentasi, dan agket. Dalam penelitian ini menggunakan metode analisis deskriptif. Angka-angka hasil perhitungan atau pengukuran dapat diproses dengan cara menjumlahkan, membandingkan dengan jumlah yang diharapkan oleh presentasi. Pancaran persentase dimaksudkan untuk mengetahui status sesuatu yang dipersentasikan lalu ditafsirkan dengan kalimat.

Teknik awal deskriptif digunakan untuk mengetahui faktor-faktor dan kendala yang mempengaruhi minat baca. Untuk mengetahui hal tersebut ditempuh langkah-langkah sebagai berikut:

(a)Membuat tabulasi jawaban angket dari responden

(b)Membuat skor jawaban dengan ketentuan yang telah ditetapkan

(c)Menentukan skor yang telah diperoleh dari tiap-tiap responden

(d)Mencari persentase skor yang diperoleh dengan menggunakan rumus:

$$
\mathrm{DP}=\frac{N}{n} 100 \%
$$

Keterangan :

DP = Deskriptif Persentase

$\mathrm{n} \quad=$ nilai yang diperoleh

$\mathrm{N} \quad=$ jumlah seluruh nilai yang diharapkan 


\section{HASIL PENELITIAN}

Hasil penelitian ini meliputi hasil observasi, hasil wawancara, hasil angket (kuesioner) dan hasil dokumentasi yang kemudian dianalisis dan disajikan dalam bentuk gambar, tabel data, serta pembahasan secara deskripsi. Hal tersebut berguna untuk menjawab permasalahan mengenai kondisi dan kendala dalam menumbuhkan minat baca mahasiswa semester 5 PGSD UPGRIS. Berikut ini hasil yang diperoleh:

\section{Kondisi Minat Baca Mahasiswa}

Berdasarkan hasil angket yang dibagikan terhadap responden menyatakan hasil yang kurang memuaskan. Hasil wawancara dan observasi menunjukkan bahwa kondisi minat baca mahasiswa semester 5 PGSD UPGRIS masih sangat rendah. Hal ini terlihat dari hasil wawancara responden pada item pedoman wawancara nomor 1 sampai 4. Selain itu, berdasarkan observasi, rendahnya minat baca mahasiswa juga dapat dilihat dari jumlah kunjungan yang ada di setiap perpustakaan kampus.

Berdasarkan hasil angket yang dibagikan kepada responden, sekitar 96,96\% responden memilki kualifikasi minat baca rendah, sedangkan sisanya yakni $3,04 \%$ responden dinyatakan memiliki minat baca sedang. Hasil analisis tersebut didasarkan atas kriteria penilaian menurut skala Arikunto (2008: 245) yang telah dimodifikasi. Berikut ini tabel frekuensi skor angket responden terhadap minat baca.

Tabel 1. Data Minat Baca Mahasiswa

\begin{tabular}{|c|c|c|}
\hline Klasifikasi & Kriteria & Persentase \\
\hline Sangat Tinggi & $81,28 \%-100 \%$ & $0,00 \%$ \\
\hline Tinggi & $62,50 \%-81,27 \%$ & $0,00 \%$ \\
\hline Rendah & $43,76 \%-62,51 \%$ & $3,04 \%$ \\
\hline Sangat Rendah & $25,00 \%-43,75 \%$ & $96,96 \%$ \\
\hline \multicolumn{2}{|c|}{ Jumlah } & $100,00 \%$ \\
\hline \multicolumn{3}{|c|}{ 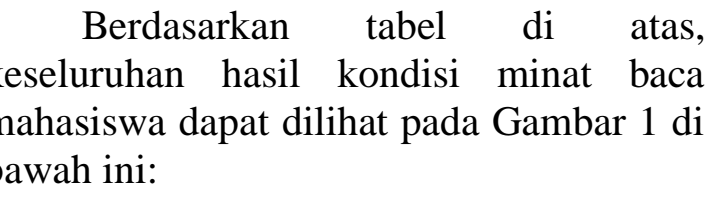 } \\
\hline
\end{tabular}

\section{Indikator Dorongan Teman atau Sekitarnya}

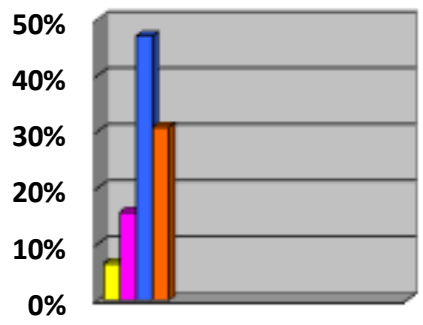

$\square$ sangat tinggi $\square$ tinggi $\square$ rendah $\square$ sangat rendah

Gambar. 1 Persentase Skor Minat Baca

Berdasarkan diagram kondisi minat baca pada Gambar 1 di atas, hasil skor angket responden terhadap minat baca mahasiswa semester 5 PGSD UPGRIS dengan rincian sebagai berikut: $96,96 \%$ responden memiliki minat baca yang sangat rendah, 3,04\% responden memiliki minat baca yang rendah, dan tidak ada responden yang dinyatakan memiliki minat baca tinggi, maupun sangat tinggi.

\section{Kendala Mahasiswa dalam Menumbuhkan Minat Baca}

Kendala dalam menumbuhkan minat baca mahasiswa PGSD UPGRIS semester 5 terdiri dari 6 indikator yaitu kelemahan fisik, intelegensi, minat, bakat, kebiasaan, dan banyaknya beban belajar. Jawaban responden dapat diuraikan sebagai berikut:

a) Kelemahan fisik

Berdasarkan hasil penelitian jawaban responden tentang indikator kelemahan fisik dapat terangkum dalam Tabel 2 berikut ini.

Tabel 2 Deskripsi Persentase Indikator Kelemahan Fisik

\begin{tabular}{ccc}
\hline Klasifikasi & \multicolumn{1}{c}{ Kriteria } & Persentase \\
\hline Sangat Tinggi & $81,28 \%-100 \%$ & $31,72 \%$ \\
\hline Tinggi & $62,50 \%-81,27 \%$ & $20,22 \%$ \\
\hline Rendah & $43,76 \%-62,51 \%$ & $36,42 \%$ \\
\hline Sangat Rendah & $25,00 \%-43,75 \%$ & $31,72 \%$ \\
\hline \multicolumn{2}{c}{ Jumlah } & $\mathbf{1 0 0 , 0 0 \%}$ \\
\hline
\end{tabular}


Berdasarkan Tabel 2 di atas, indikator kelemahan fisik juga dapat dilihat pada Gambar 2 di bawah ini:

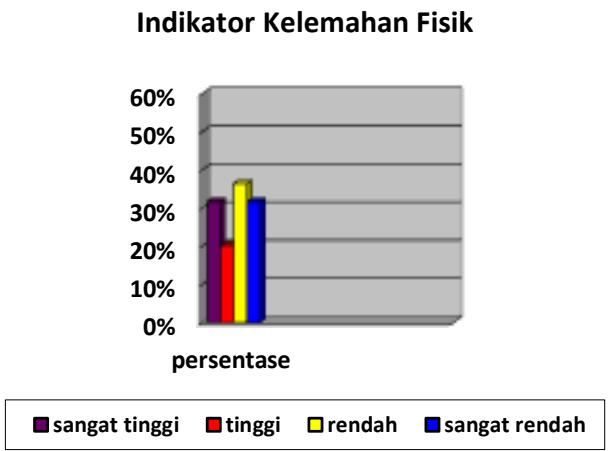

Gambar. 2 Indikator Kelemahan Fisik

Berdasarkan Gambar 2 di atas, menunjukkan bahwa mahasiswa memilih indikator kelemahan fisik sebagai kendala menumbuhkan minat baca dalam kategori sangat tinggi sebanyak $31,72 \%$, tinggi sebesar $20,22 \%$, rendah $36,42 \%$, sedangkan yang termasuk dalam kategori sangat rendah sebanyak $31,72 \%$. Oleh karena itu, dapat disimpulkan bahwa indikator kelemahan fisik menjadi salah satu kendala dalam menumbuhkan minat baca mahasiswa. Hal ini dapat dibuktikan dengan banyaknya mahasiswa yang memilih item di atas sebanyak 36,42\% termasuk dalam kategori rendah.

b) Intelegensi

Berdasarkan hasil penelitian jawaban responden tentang indikator intelegensi dapat terangkum dalam Tabel 3 berikut ini.

Tabel 3 Persentase Indikator Intelegensi

\begin{tabular}{ccc}
\hline Klasifikasi & Kriteria & Persentase \\
\hline Sangat Tinggi & $81,28 \%-100 \%$ & $23,22 \%$ \\
\hline Tinggi & $62,50 \%-81,27 \%$ & $25,42 \%$ \\
\hline Rendah & $43,76 \%-62,51 \%$ & $31,32 \%$ \\
\hline Sangat Rendah & $25,00 \%-43,75 \%$ & $20,03 \%$ \\
\hline Jumlah & $\mathbf{1 0 0 , 0 0 \%}$ \\
\hline Berdasarkan Tabel 3 di atas, \\
indikator intelegensi juga dapat dilihat \\
pada Gambar 3 di bawah ini: \\
Gambar. 3 Indikator Intelegensi
\end{tabular}

Indikator Intelegensi

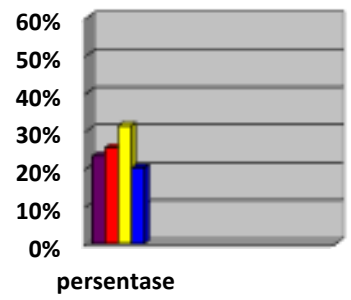

$\square$ sangat tinggi $\square$ tinggi $\square$ rendah $\square$ sangat rendah

Berdasarkan Gambar 3 di atas, menunjukkan bahwa sebagian mahasiswa memilih indikator intelegensi dalam kategori sangat tinggi sebanyak 23,22\%, kategori tinggi sebanyak 25,42\%, kategori rendah $31,32 \%$, sedangkan yang termasuk dalam kategori sangat rendah sebanyak $20,03 \%$. Oleh karena itu, dapat disimpulkan bahwa indikator intelegensi menjadi salah satu kendala dalam menumbuhkan minat baca mahasiswa. Hal ini dapat dibuktikan dengan banyaknya mahasiswa yang memilih item di atas sebanyak $31,32 \%$ termasuk dalam kategori rendah.

c) Minat

Berdasarkan hasil penelitian jawaban responden tentang indikator minat yang baik dapat terangkum dalam Tabel 4 berikut ini.

Tabel 4 Persentase Indikator Minat

\begin{tabular}{|c|c|c|}
\hline Klasifikasi & Kriteria & Persentase \\
\hline Sangat Tinggi & $81,28 \%-100 \%$ & $13,14 \%$ \\
\hline Tinggi & $62,50 \%-81,27 \%$ & $21,21 \%$ \\
\hline Rendah & $43,76 \%-62,51 \%$ & $37,37 \%$ \\
\hline Sangat Rendah & $25,00 \%-43,75 \%$ & $28,28 \%$ \\
\hline \multicolumn{2}{|c|}{ Jumlah } & $100,00 \%$ \\
\hline
\end{tabular}

Berdasarkan Tabel 4 di atas, indikator minat juga dapat dilihat pada Gambar 4 di bawah ini: 


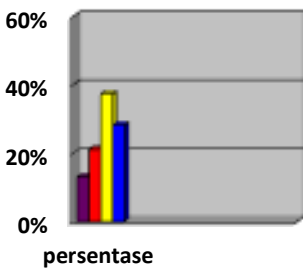

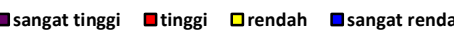

Gambar. 4 Indikator Minat

Berdasarkan Gambar 4 di atas, menunjukkan bahwa sebagian mahasiswa memilih indikator minat dalam kategori sangat tinggi sebanyak $13,14 \%$, kategori tinggi sebanyak $21,21 \%$, kategori rendah sebanyak $37,37 \%$, sedangkan yang termasuk dalam kategori sangat rendah sebanyak $28,28 \%$. Oleh karena itu, dapat disimpulkan bahwa indikator minat menjadi salah satu kendala dalam menumbuhkan minat baca mahasiswa. Hal ini dapat dibuktikan dengan banyaknya mahasiswa yang memilih item di atas sebanyak $37,37 \%$ termasuk dalam kategori rendah.

d) Bakat

Berdasarkan hasil penelitian jawaban responden tentang indikator bakat dapat terangkum dalam Tabel 5 berikut ini.

Tabel 5 Persentase Indikator Bakat

\begin{tabular}{ccc}
\hline Klasifikasi & Kriteria & Persentase \\
\hline Sangat Tinggi & $81,28 \%-100 \%$ & $20,70 \%$ \\
\hline Tinggi & $62,50 \%-81,27 \%$ & $26,27 \%$ \\
\hline Rendah & $43,76 \%-62,51 \%$ & $42,42 \%$ \\
\hline Sangat Rendah & $25,00 \%-43,75 \%$ & $10,61 \%$ \\
\hline \multicolumn{2}{c}{ Jumlah } & $\mathbf{1 0 0 , 0 0 \%}$ \\
\hline
\end{tabular}

Berdasarkan Tabel 5 di atas, indikator bakat juga dapat dilihat pada Gambar 5 di bawah ini: Indikator Bakat

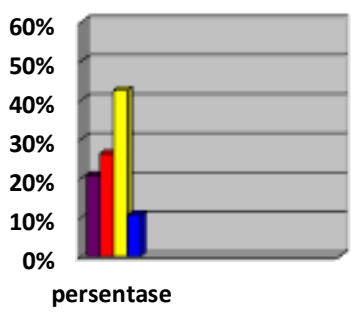

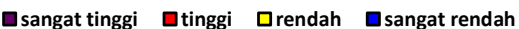

Gambar. 5 Indikator Bakat
Berdasarkan Gambar 5 di atas, menunjukkan bahwa sebagian mahasiswa memilih indikator bakat sebagai kendala yang mempengaruhi minat baca dalam kategori sangat tinggi sebanyak 20,70\%, kategori tinggi sebanyak 26,27\%, kategori rendah $42,42 \%$, sedangkan yang termasuk dalam kategori sangat rendah sebanyak $10,61 \%$. Oleh karena itu, dapat disimpulkan bahwa indikator bakat menjadi salah satu kendala dalam menumbuhkan minat baca mahasiswa. Hal ini dapat dibuktikan dengan banyaknya mahasiswa yang memilih item di atas sebanyak $42,42 \%$ termasuk dalam kategori rendah.

e) Kebiasaan

Berdasarkan hasil penelitian jawaban responden tentang indikator kebiasaan dapat terangkum dalam Tabel 6 berikut ini.

Tabel 6 Persentase Indikator Kebiasaan

\begin{tabular}{ccc}
\hline Klasifikasi & Kriteria & Persentase \\
\hline Sangat Tinggi & $81,28 \%-100 \%$ & $6,46 \%$ \\
\hline Tinggi & $62,50 \%-81,27 \%$ & $19,80 \%$ \\
\hline Rendah & $43,76 \%-62,51 \%$ & $27,88 \%$ \\
\hline Sangat Rendah & $25,00 \%-43,75 \%$ & $45,86 \%$ \\
\hline \multicolumn{2}{c}{ Jumlah } & $\mathbf{1 0 0 , 0 0 \%}$ \\
\hline
\end{tabular}

Berdasarkan Tabel 6 di atas, indikator kebiasaan juga dapat dilihat pada Gambar 6 di bawah ini:

Indikator Kebiasaan

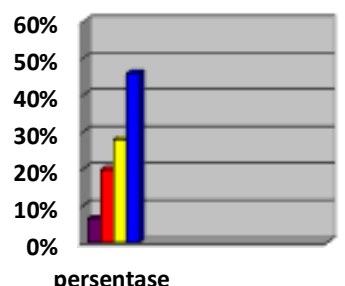

Qsangat tinggi $\square$ tinggi $\square$ rendah $\square$ sangat rendah

Gambar 6 Indikator Kebiasaan

Berdasarkan Gambar 6 di atas, menunjukkan bahwa sebagian mahasiswa memilih indikator kebiasaan sebagai kendala menumbuhkan minat baca dalam kategori sangat tinggi 
sebanyak 6,46\%, kategori tinggi sebanyak 19,80\%, kategori rendah $27,88 \%$, sedangkan yang termasuk dalam kategori sangat rendah sebanyak $45,86 \%$. Oleh karena itu, dapat disimpulkan bahwa indikator kebiasaan menjadi salah satu kendala dalam menumbuhkan minat baca mahasiswa. Hal ini dapat dibuktikan dengan banyaknya mahasiswa yang memilih item di atas sebanyak 45,86\% termasuk dalam kategori sangat rendah.

f) Banyaknya beban belajar

Berdasarkan hasil penelitian jawaban responden tentang indikator banyaknya beban belajar dapat terangkum dalam Tabel 7 berikut ini.

Tabel 7 Persentase Indikator

Banyaknya Beban Belajar

\begin{tabular}{|c|c|c|}
\hline Klasifikasi & Kriteria & Persentase \\
\hline Sangat Tinggi & $81,28 \%-100 \%$ & $18,19 \%$ \\
\hline Tinggi & $62,50 \%-81,27 \%$ & $31,31 \%$ \\
\hline Rendah & $43,76 \%-62,51 \%$ & $38,38 \%$ \\
\hline Sangat Rendah & $25,00 \%-43,75 \%$ & $12,12 \%$ \\
\hline \multicolumn{2}{|c|}{ Jumlah } & $100,00 \%$ \\
\hline \multicolumn{3}{|c|}{$\begin{array}{l}\text { Berdasarkan Tabel } 7 \text { di atas, } \\
\text { indikator kebiasaan juga dapat dilihat } \\
\text { pada Gambar } 7 \text { di bawah ini: } \\
\text { Indikator Banyaknya Beban Belajar }\end{array}$} \\
\hline \multicolumn{3}{|l|}{$60 \%$} \\
\hline \multicolumn{3}{|l|}{$50 \%$} \\
\hline \multicolumn{3}{|l|}{$40 \%$} \\
\hline \multicolumn{3}{|l|}{$30 \%$} \\
\hline \multicolumn{3}{|l|}{$20 \%$} \\
\hline \multicolumn{3}{|c|}{$10 \%$} \\
\hline \multicolumn{3}{|c|}{$0 \%$ persentase } \\
\hline Dsangat tinggi & 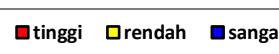 & \\
\hline
\end{tabular}

Gambar. 7 Indikator Banyaknya Beban Belajar

Berdasarkan Gambar 7 di atas, menunjukkan bahwa sebagian mahasiswa memilih indikator banyaknya beban belajar sebagai kendala menumbuhkan minat baca dalam kategori sangat tinggi sebanyak $18,18 \%$, kategori tinggi sebanyak $31,31 \%$, kategori rendah sebanyak $38,38 \%$, sedangkan yang termasuk dalam kategori sangat rendah sebanyak $12,12 \%$. Oleh karena itu, dapat disimpulkan bahwa indikator banyaknya beban belajar menjadi salah satu kendala dalam menumbuhkan minat baca mahasiswa. Hal ini dapat dibuktikan dengan banyaknya mahasiswa yang memilih item nomor 49 dan 50 sebanyak $38,38 \%$ termasuk dalam kategori rendah.

Berdasarkan perhitungan dari beberapa indikator di atas tentang kendala dalam menumbuhkan minat baca mahasiswa PGSD UPGRIS semester 5 terdiri dari 6 indikator yaitu kelemahan fisik, intelegensi, minat, bakat, kebiasaan, dan banyaknya beban belajar menghasilkan rata-rata sebesar $42,42 \%$. Hal ini menyatakan bahwa kendala yang dihadapi mahasiswa termasuk dalam kategori sedang.

\section{PEMBAHASAN}

\section{Kondisi Minat Baca Mahasiswa}

Berdasarkan hasil penelitian yang diperoleh menunjukkan bahwa kondisi minat baca mahasiswa PGSD UPGRIS semester 5 pada tahun 2017 secara keseluruhan memiliki minat baca yang rendah. Hal ini memberikan gambaran bahwa mahasiswa kurang memiliki keinginan untuk membaca buku baik buku pegangan mata kuliah maupun buku-buku lainnya. Mahasiswa masih menganggap bahwa membaca masih kurang penting, selain itu mereka tidak memiliki motivasi yang tinggi untuk membaca buku.

Aktivitas membaca mahasiswa mengalami penurunan kemungkinan dipengaruhi juga oleh teknologi informasi yang sudah sangat maju. Berbagai macam hiburan yang tidak mengikutsertakan media buku, menjadi lebih menarik, karena membaca membutuhkan perhatian khusus yang tidak dapat diselingi dengan aktivitas lain. Kondisi tersebut terjadi dengan seiring berkembangnya sosial media di lingkungan mahasiswa, mahasiswa cenderung tertarik dengan membaca media sosial ketimbang membaca buku disela-sela kegiatan 
mereka. Bahkan di saat waktu luang pun mereka tidak ada dorongan untuk membaca buku.

Selain itu, kurangnya minat membaca pada mahasiswa dapat dilihat dari partisipasi mahasiswa di kelas saat mengikuti perkuliahan. Peneliti banyak menemui mahasiswa yang sulit dan enggan untuk bertanya tentang materi yang diberikan dosen. Bahkan, mahasiswa cenderung diam dan menerima semua informasi yang diberikan dosen tanpa ada yang bertanya. Mereka juga jarang memberikan kritik, pendapat ataupun idenya. Pada saat dosen menanyakan alasan mahasiswa tidak mau bertanya, kebanyakan mahasiswa merasa bingung dan tidak mampu untuk bertanya. Sebagian mahasiswa yang bertanya, pertanyaan yang diajukan juga tidak bermutu atau tidak kritis. Di sisi lain, kualitas pertanyaan sebenarnya dapat ditelusuri dari hasil bacaan yang mereka baca. Mahasiswa yang tidak mampu bertanya ataupun memberikan pertanyaan tidak berkualitas, kemungkinan karena sebelumnya mereka tidak membaca tentang materi yang diberikan dosen.

Rendahnya minat baca mahasiswa juga dapat dilihat dari tingkat kunjungan mahasiswa ke perpustakaan yang jarang dilakukan. Para mahasiswa lebih memilih untuk berada di ruang kelas, bercerita dengan temannya, atau bermain dengan gadget dibandingkan dengan membaca buku ke perpustakaan. Rendahnya minat baca mahasiswa disebabkan kurangnya rasa memiliki, perhatian terhadap buku dan manfaat membaca, serta motivasi dari diri sendiri maupun dari orang lain (lingkungan).

\section{Kendala dalam Menumbuhkan Minat Baca}

Kendala dalam menumbuhkan minat baca mahasiswa PGSD UPGRIS semester 5 sebagian besar termasuk dalam kategori sedang. Hal ini memberikan gambaran bahwa adanya kelemahan-kelemahan baik fisik maupun non-fisik yang menghambat proses pemahaman isi buku yang mereka baca. Rasa suka terhadap buku-buku perkuliahan maupun buku-buku lainnya yang sebagian besar masih belum dapat menyukai dengan baik, hal itulah yang menjadikan masalah mengapa perkuliahan belum berlangsung dengan maksimal.

Intelegensi, bakat, dan minat mahasiswa dalam membaca atau melakukan kegiatan membaca juga menjadi kendala yang penting bagi tumbuhnya minat baca mahasiswa. Mahasiswa yang memiliki kekurangan dalam hal intelegensi tentu akan berpikir dua kali untuk melakukan kegiatan membaca. Berbeda dengan yang memiliki intelegensi tinggi tentu minat untuk membaca tinggi atau bahkan sudah menyediakan waktu untuk membaca. Disamping itu, menumbuhkan minat baca juga dipengaruhi oleh beban mahasiswa untuk menguasai semua materi perkuliahan. Selain itu, keaktifan mahasiswa dalam kegiatan-kegiatan di luar perkuliahan bahkan juga aktivitas lainnya yang mungkin ada waktu luang tetapi dimanfaatkan hanya untuk bermain dengan gadget mereka juga berpengaruh terhadap minat baca mahasiswa.

\section{SIMPULAN}

1. Kondisi minat baca mahasiswa PGSD UPGRIS semester 5 masih rendah. Hal ini dapat dilihat dari hasil skor angket menghasilkan $96,96 \%$ responden memiliki minat baca yang sangat rendah, $3,04 \%$ responden memiliki minat baca yang rendah, dan tidak ada responden yang dinyatakan memiliki minat baca sedang, tinggi maupun sangat tinggi.

2. Kendala yang dihadapi mahasiswa PGSD UPGRIS semester 5 dalam menumbuhkan minat baca yang terdiri dari enam indikator yakni, kelemahan fisik, intelegensi, minat, bakat, kebiasaan, dan banyaknya beban belajar menghasilkan rata-rata sebesar $42,42 \%$. Hal ini menyatakan bahwa kendala yang dihadapi mahasiswa termasuk dalam kategori sedang. 


\section{DAFTAR PUSTAKA}

Anggun. 2017. Implementation of $1^{\text {st }}$ Century Skills Competence through Improve Learning Quality. Disampaikan pada Seminar Internasional ICERD 2017 di UPI Bandung, 20 November 2017.

Arikunto. 2008. Metodologi Penelitian Kualitatif. Bandung: Remaja Rosda Karya.

Slameto. 2010. Belajar dan Faktor-faktor yang Mempengaruhinya. Jakarta: Rineka Cipta.

Sugiharto. (2012). Menyongsong Indonesia Emas 2045. Disampaikan pada Kuliah Perdana Universitas Sarjanawiyata Tamansiswa (UST) Yogyakarta. 17 September 2012.

Syah. 2003. Psikologi Belajar. Jakarta: PT. Raja Grafindo Persada.

Pikiran Rakyat, 17 Maret 2017 diperoleh dari http://www.pikiranrakyat.com/pendidikan/2017/03/17/soal-minat-baca-indonesia-peringkat-60-dari-61negara-396477 pada tanggal 29 September 2017

Rahim, F. 2008. Pengajaran Membaca di Sekolah Dasar. Jakarta: Bumi Aksara. 